\title{
Constraints on Farmers Access to Agricultural Information Delivery: A Survey of Rural Farmers in Yobe state, Nigeria
}

\author{
Galadima. M. \\ Department of Sociology, Km 7, Yobe State University Damaturu, Nigeria.
}

\begin{abstract}
This study examines the constraints on farmers' access to Agricultural information delivery: a Survey of rural farmers in Yobe state, Nigeria. The socio-economic characteristics of farmers were described, major sources of information to farmers were determined and various constraints faced by farmers on information delivery in the study area. In order to examine the constraints of farmers on their access to agricultural information delivery in Yobe state, all the three senatorial zones of the State were selected; taking one Local Government Area from each zone. Data were collected using well structured questionnaire and analysed through the use of descriptive statistics'. From the findings of the research, out of the 160 respondents $51 \%$ were male while $49 \%$ were female with ages ranging from 20 to 65 with an average of 40 years. While $97 \%$ of the respondents were married, majority (80\%) having household size of less than 10 members, whereas, $68 \%$ had formal education. Majority of the respondents has spent 4-6 years as members of cooperative societies. While (63\%) of the respondents had between 10 and 20 years of experience on farming and $56 \%$ had no access to credit facilities. The result further showed that rural farmers in the study area obtained their sources of information through; television, radio, extension workers and ward heads. The results on sources of information to farmers have clearly indicated that extension agents had the highest percentage with $62 \%$ over others. It was further revealed that, irrelevant information; delay on information delivery, extension workers' personalities, and lack of feedback mechanism were identified as constraints facing farmers in the study area. It thus, recommended that, rural farmers in the study area need to make use of electronic media as their major sources of information and government should provide relevant infrastructure available particularly; sources of power to enhance the usage of the media recommended. The extension agents in the study area should be more committed to their duties, more approachable and also improves their feedback mechanism promptly. More so, farmers should also be encouraged in the formation of co-operative groups so as to pull their resources together to improve their financial capability vis-à-vis improve their innovative skills in the course of group interaction

Keywords: Constraints, Farmers, Information Delivery, Source,
\end{abstract}

\section{Introduction}

The concern over the effective information delivery to farmers as means of updating their knowledge on farming activities is one of the major issues in contemporary Nigerian society. It is a fact, rural farmers lack access to knowledge and information that would help them achieve maximum agricultural yield, they are not only grope in the dark but are driven to the urban centers in search of formal employment, as the only option for survival (Munyua, 2000). In the same manner, Blait (1996) pointed out that the least expensive input for improved rural agricultural development is adequate access to knowledge and information in areas of new agricultural technologies, early warning systems (drought, pests, diseases etc), improved seedlings, fertilizer, credit, market prices etc. In words of (Van and Fortier, 2000), there have been short-comings of traditional print and library based methods of providing such agricultural information to rural farmers who are generally illiterate and relatively remote from formal sources of information (e.g. extension stations, libraries). Thus, Aina (2007) noted that farmers could benefit from global information, if information centers are cited in rural areas, equipped with all information and communication gadgets. It should however, be noted that information needed by the rural farmers in Nigeria and elsewhere, could be according to their needs. Hence, their needs could be on how to control pest and diseases, environmental hazards, seedlings, preservation, finance and non access to loan. There is a saying that information is power. If enough information needed by rural farmers is repackaged in the language they will understand and given to them at the appropriate time, Nigeria should be able to achieve food security. The drive to achieve the food security and national development objectives as espoused in the 7-point agenda makes the strengthening of Agricultural production, storage and marketing as well as research and development imperative. 
Amobi (2010) observed that national food security programme is meant to to ensure sustainable access, availability and affordability of equality of food to all Nigerians for the country to become a significant provider of food to the global community. For this task to be successful, effective information dissemination to farmers is very imperative. Hence, mass media is one of the major sources of information that can be very helpful in creating awareness and changing the behavior of farmers towards better utilization of research findings and proper management of their resources. Several researches have shown that the role played by information for rural people who do not have access to the information which farmers needed as regards to technology and such information can be supplemented with radio which is a very good medium for supplying information at the awareness stage in the adoption process in learning (Agada, 2003). In the same manner, Ozowa (1995) identified the problems of agricultural information or communication as follows: One of the obvious constraints in the use of the broadcasting media in Nigeria is poor reception quality and the area covered. The messages carried are not tailored to the information needs of rural populations. Even when the information is irrelevant, it is seldom aired at the proper time and so does not get to the targeted audience. The use of print media, leaflets and newsletters as message carriers are of limited use in reaching illiterate farmers. Technical language used in communicating information is incomprehensible to the farmers. Lastly, many people in extension are ill prepared for extension and an extension communication job. Hence an enormous gap exists between available knowledge of improved technology and actual practice; this has had considerable effects in an attempt to increase food production (Adebo, 2005). This study therefore, examines the constraints on farmers' access to agricultural information delivery, a survey of rural farmers in Yobe State.

\section{Methodology}

The study was carried out in Yobe State. The State is located in the North East zone of Nigeria with its headquarters at Damaturu. It lies between latitude $12^{\circ} 00^{\prime} \mathrm{N}$ and longitude $11.30^{\circ} \mathrm{E}$, covering a land area of about 45,502 square kilometers (km2), with a population of about 2,321,591 people (NPC, 2006).

However, in order to examine the constraints on farmers' access to agricultural information delivery in rural Yobe state, all the three senatorial zones of the State were selected; taking one Local Government Area from each zone that participated in farming as their major occupation. The zones include: Northern senatorial zone; Central and South Zone respectively. To determine the sample size of the population in the study area, a multistage sampling technique was employed to get the respondents. In the first stage, three Local Government Areas were purposively selected in each zone: Machina in Northern zone, Gulani in Central and Fika in South zone, out of the seventeen LGAs in Yobe state, for easy accessibility and to cut across the State. In the second stage, simple random sampling technique was used to select two villages from each Local Government Area, making a total of six villages. Thirdly, $10 \%$ of the population was randomly selected from each village, which forms the sample size of (160) of the total population. The data collected includes; socio-economic characteristics of respondents in the study area, major sources of information to farmers and various constraints faced by farmers on information delivery in the study area. The data collected were analyzed using descriptive statistics, involving frequencies and percentages.

\section{Results And Discussion}

This section presents the results and discussion of the data obtained from respondents, on their socioeconomic characteristics.

\section{Socio-economic Characteristics of Respondents}

The socio-economic characteristics of the respondents identified include; Gender, Age, Marital Status, Household Size, Level of education, Membership of cooperative society, farming experience and Access to Credit. Evidence from the descriptive analysis of socio-economic characteristics of the respondents in the study area is shown in Table 1, it revealed that $51 \%$ of the respondents were male and $49 \%$ were female. This showed that both gender were adequately represented, with little variation in favour of male respondents, which may be as a result of the cultural barrier in the area of not allowing women to come out and participate in any activities freely. The data in Table 1 also, revealed that the age of the respondents ranged between 20 and 65 years with an average of 40 years. This implies that, the respondents are middle aged and so still active and can participate adequately in farming activities. It was equally observed in Table 1 that $97 \%$ of the respondents were married and 3\% were single. This shows that most of the respondents will have greater responsibility than the single, which may encourage respondents to be committed towards their participation in farming activities. As noted by Perez- Morales (1996), there is a trend for rural youth to start having responsibilities at an earlier age than urban youth. Hence, the tendency to marry early helps in building a virile farming population. In the same manner, the result in Table 1 indicates that about half (49\%) of the respondents had 6-10 people in their households, while, $31 \%$ had household size of less than 6 people. Table 1 also, reveals that about $68 \%$ of the respondents had formal education. Such level of education is expected to have positive impact on the respondents' participation 
in the farming activities. The respondents with no formal education were about $32 \%$. The result also indicates that, Respondents in the study area belong to cooperative society; the maximum number of years spent as members of cooperative society was 9 years and a minimum of 1 year. Respondents with $4-6$ years of membership duration constitute $61 \%$ while $20 \%$ had $1-3$ years of membership of cooperative society (Table 1 ). With this level of membership duration, it could be said that majority of the respondents have had long duration of experience as members of cooperative group which can facilitate understanding of agricultural information due to the interaction among members. The result in Table 1 revealed that majority $(62 \%)$ of the beneficiaries had between 4 and 6 years of experience in farming activities, while $24 \%$ of the respondents had experience of 7 to 9 years and the lowest percentage (13\%) falls within 1to 3 years of experience in farming. These years of experience in the farming activities were expected to translate into better utilization and understanding of the agricultural information which may invariably result into better income as well a standard of living. On respondents' access to credit facilities, it was equally observed in Table 1 that $56 \%$ of the respondents had no access to credit facilities. Ekong (2003) asserts that credit is a very strong factor that is needed to acquire or develop any enterprise; its availability could determine the extent of production capacity.

Table 2: Socio-economic characteristics of respondents

\begin{tabular}{|c|c|c|c|}
\hline Variable & Frequency & Percentages & Mean \\
\hline \multicolumn{4}{|l|}{ Gender } \\
\hline Male & 82 & 51.2 & \\
\hline Female & 78 & 48.9 & \\
\hline \multicolumn{4}{|l|}{ Age (years) } \\
\hline $20-29$ & 19 & 11.9 & \\
\hline $30-39$ & 52 & 32.2 & 40 \\
\hline $40-49$ & 54 & 33.8 & \\
\hline $50-59$ & 34 & 21.2 & \\
\hline $60-69$ & 1 & 0.6 & \\
\hline \multicolumn{4}{|l|}{ Marital status } \\
\hline Married & 156 & 97.5 & \\
\hline Single & 4 & 2.5 & \\
\hline \multicolumn{4}{|l|}{ Household size } \\
\hline $0-5$ & 49 & 30.6 & \\
\hline 6-10 & 78 & 48.8 & \\
\hline $11-15$ & 29 & 18.2 & \\
\hline $16-20$ & 3 & 1.9 & \\
\hline $21-25$ & 1 & 0.6 & \\
\hline \multicolumn{4}{|c|}{ Level of education } \\
\hline No education & 51 & 31.9 & \\
\hline Adult education & 21 & 13.1 & \\
\hline Primary & 34 & 21.2 & \\
\hline Secondary & 38 & 23.8 & \\
\hline Tertiary & 5 & 3.1 & \\
\hline Others & 11 & 6.9 & \\
\hline \multicolumn{4}{|c|}{ Membership of cooperative society (yrs) } \\
\hline Non members & 5 & 3.1 & \\
\hline $1-3$ & 32 & 20.0 & \\
\hline $4-6$ & 97 & 60.6 & \\
\hline $7-9$ & 26 & 16.2 & \\
\hline \multicolumn{4}{|c|}{ Farming Experience (yrs) } \\
\hline $1-5$ & 21 & 13.1 & \\
\hline $5-10$ & 100 & 62.5 & \\
\hline 10 - above & 39 & 24.4 & \\
\hline \multicolumn{4}{|l|}{ Access to credit } \\
\hline None & 89 & 55.6 & \\
\hline Access & 71 & 44.4 & \\
\hline Total & 160 & 100 & \\
\hline
\end{tabular}

Source: Field Survey, 2013

Farmers Sources of Information in the Study Area.

The data in Table 2. Indicates, various sources that farmers receive their information on new technology/innovations which are: television (T.V), Radio, Extension agents, and Ward head. It was also revealed that, farmers obtained most of their information on new technology from extension workers with $62 \%$ followed by radio with $19 \%$ and least channel of information to the farmers is television with $9 \%$, this is as a result of literacy level of the farmers, affordability and power source to operate television. The extension agents are not using this media much to reach out to farmers, but prefer to contact farmers themselves. Using these media would have been faster ways of reaching farmers with little effort and much success. 
Table 2. Distribution of farmers based on their various sources of information Delivery.

\begin{tabular}{lll}
\hline Sources of Information & Frequency & Percentages \\
\hline Television(T.V) & 15 & 9.3 \\
Radio & 30 & 18.7 \\
Extension Agents & 99 & 61.8 \\
Ward Head & 16 & 10.0 \\
Total & $\mathbf{1 6 0}$ & $\mathbf{1 0 0 . 0}$ \\
\hline
\end{tabular}

Source: Field survey, 2013.

\section{Constraints faced by farmers on information delivery in the study area}

Various constraints were discovered which militate against information delivery to farmers such as, the Information type, Information needs, information barrier, extension agent personality, feedback and timeliness of feedback mechanism. Therefore, the results in table 3 showed that farmers received information majorly on seeds with highest percentage $53 \%$ and the least is from agrochemicals with percentage 0 f $19 \%$. The table also showed that the information needs of the farmers are majorly on fertilizer with a percentage of $22 \%$. This means information received by the farmers is not directly meeting the need of the farmers. The result in Table 3 also indicates that, Information delayed had the highest percentage of $65 \%$ among other barriers. This showed that farmers were not getting the information as at when due, and information delayed is information denied, the table further showed that language barriers with $13 \%$ which indicates that various sources of information to the farmers are in local language which is better understood by the farmers. The findings in Table 3 further showed that, the majority of extension workers were fairly approachable but not fully approachable. They were $74 \%$ fairly approachable but $26 \%$ were fully approachable. This will prevent farmers to open up fully to the farmers on their problems, thus they become reserved which would not help and their problems will remain. It was also indicate on the results that, majority of farmers were not getting feedback from extension workers as were suppose to; that means the feedback is not timely.

Table 3. Distribution of farmers According to the Constraints hindering Agricultural information delivery in the study area.

\begin{tabular}{llc}
\hline Factors & Frequency & Percentages \\
\hline Information Received & 15 & \\
Fertilizer & 100 & 9.3 \\
Seeds & 15 & 62.5 \\
Agrochemicals & 30 & 9.3 \\
Credits & & 18.7 \\
& 25 & \\
Information Needs & 85 & 21.87 \\
Fertilizer & 30 & 53.12 \\
Seeds & 20 & 18.75 \\
Agrochemicals & & 12.50 \\
Others & 20 & \\
Information Constraints & 104 & 12.50 \\
Language barrier & 23 & 65.00 \\
Delayed Information & 14 & 14.37 \\
Irrelevant Information & & 8.75 \\
Others & 42 & \\
Extension Personality & 118 & 26.25 \\
Approachable & 24 & 73.75 \\
Fairly approachable & & 15.00 \\
Others & 60 & \\
Feed Back & 100 & 37.50 \\
Yes & & 62.50 \\
N0 & 17 & 10.62 \\
Timeliness of Feedback & 46 & 28.75 \\
Fast & 97 & 60.62 \\
Slow & $\mathbf{1 6 0}$ & $\mathbf{1 0 0}$ \\
Late & & \\
Total & & \\
\hline
\end{tabular}

Source: Field Survey, 2013.

\section{Conclusion}

From the study, it could be concluded that, the sources of information to rural farmers were from; television, radio, extension workers, and ward leaders. It was also discovered that the factors militating against the information delivery are; Irrelevant information, information delayed, extension workers' personalities, language barriers and lack of feedback in the study area. It thus recommends that, irrelevant information should not disseminated and the information in question should always reach the rural farmers in good time. More so, 
the feedback mechanism should be strengthened and the extension workers should learn how to adjust to the situations while there on the field.

\section{References}

[1]. Agada, S. (2003). The Role of Mass Media in Enhancing Farmers in the Eastern part of Kogi State. Unpublished Undergraduate Project, Department of mass communication, Kogi State University, Anyigba.

[2]. Aina, L.O. (2007). Globalisation and Small- Scale Farming in Africa: What role for Information Centres? World libraries and information congress 73rd IFLA General conference and council. Durban, South Africa.

[3]. Amobi, BO. 2010. Solving Unemployment Problems through Sustainable Agricultural Production.President's address delivered at $34^{\text {th }}$ Annual Conference of Nigeria Statistical Association held in Owerri from $22^{\text {nd }}-24^{\text {th }}$ Sept, 2010

[4]. Balit, S., Calvelo Rios, M., \& Masias, L. (1996). Communication for development for Latin America: a regional experience. FAO, Rome Italy.

[5]. Ben, A.W and Hawkins, H.S (1996). Agricultural Extension. Blackard science, Australia, ed 2. Pp218

[6]. Imebeogu N.I.O. (2002). Relevance of Technology System Farmers Experience. A. udealor, T.O. Ezulike and J.Aham (eds) Agricultural Technology Generation and Transfer Strategies for Food Security, Umidike, Nigeria.

[7]. Lai O. and Lanre, A.(1990). Communication and Rural Development in Nigeria. Millenium Investments Ltd.,Abeokuta Ogun State, Nigeria. pp.14-15.

[8]. Munyua, H. (2000). Application of information communication technologies in the agricultural sector in Africa: a gender perspective. In: Rathgeber, E, \& Adera, E.O. (Eds.) Gender and information Revolution in Africa IDRC/ECA. Pp. 85-123.

[9]. Nwachukwu,Ike (2003). Agricultural Communication: Principle and Practice. Lamb House Publishers, Umuahia, Nig. Pp.66-109

[10]. Olabimpe, A.A.(1987). The Provision of Information for rural Development .Wenilore Press Ltd. Ibadan. pp.19

[11]. Ozowa, V.N. Quarterly Bulletin of the International Association Information Specialist, IAALD/CABL. 40(1).

[12]. Van Crowder L., \&Fortier, F. (2000). National Agricultural and Rural Knowledge and Information System (NARKIS): a proposed component of the Uganda National Agricultural Advisory Service (NAADS) FAO. Pp.22. 